\title{
Halorubrum ejinorense sp. nov., isolated from Lake Ejinor, Inner Mongolia, China
}

\author{
A. M. Castillo, ${ }^{1}$ M. C. Gutiérrez, ${ }^{1}$ M. Kamekura, ${ }^{2}$ Y. Xue, ${ }^{3}$ Y. Ma, ${ }^{3}$ \\ D. A. Cowan, ${ }^{4}$ B. E. Jones, ${ }^{5}$ W. D. Grant ${ }^{6}$ and A. Ventosa ${ }^{1}$
}

Correspondence

A. Ventosa

ventosa@us.es

\author{
${ }^{1}$ Department of Microbiology and Parasitology, Faculty of Pharmacy, University of Sevilla, \\ 41012 Sevilla, Spain \\ ${ }^{2}$ Noda Institute for Scientific Research, 399 Noda, Noda-shi, Chiba-ken 278-0037, Japan \\ ${ }^{3}$ State Key Laboratory of Microbial Resources, Institute of Microbiology, Chinese Academy of \\ Sciences, 100080 Beijing, People's Republic of China \\ ${ }^{4}$ Department of Biotechnology, University of the Western Cape, Bellville 7535, Cape Town, \\ South Africa \\ ${ }^{5}$ Genencor International BV, Archimedesweg 30, 2333 CN Leiden, The Netherlands \\ ${ }^{6}$ Department of Infection, Immunity and Inflammation, University of Leicester, Leicester \\ LE1 9HN, UK
}

\begin{abstract}
A novel halophilic archaeon, strain $\mathrm{EJ}-32^{\top}$, was isolated from water from Lake Ejinor in Inner Mongolia, China. The taxonomy of strain $E J-32^{\top}$ was studied by using a polyphasic approach. On the basis of $16 \mathrm{~S}$ rRNA gene sequence similarities, strain $E J-32^{\top}$ was shown to be phylogenetically related to Halorubrum coriense (97.9\%), Halorubrum trapanicum (97.9\%), Halorubrum sodomense (97.8\%), Halorubrum tebenquichense (97.8\%), Halorubrum xinjiangense (97.6\%), Halorubrum terrestre (97.4\%), Halorubrum distributum (97.1\%) and Halorubrum saccharovorum (96.4\%). Strain EJ-32 ${ }^{\top}$ was found to be neutrophilic, non-motile and Gram-negative. It grew in medium containing saturation concentrations of $\mathrm{NaCl}$ and did not require magnesium for optimal growth. The $\mathrm{G}+\mathrm{C}$ content of the DNA is $64.0 \mathrm{~mol} \%$. Values for DNA-DNA hybridization with respect to phylogenetically related Halorubrum species were $\leqslant 49 \%$, indicating that EJ-32 ${ }^{\top}$ constitutes a different genospecies. The data show that strain EJ-32 ${ }^{\top}$ represents a novel species of the genus Halorubrum, for which the name Halorubrum ejinorense sp. nov. is proposed. The type strain is EJ-32 ${ }^{\top}\left(=\right.$ CECT $7194^{\top}=$ CGMCC $\left.1.6782^{\top}=J C M 14265^{\top}\right)$.
\end{abstract}

Hypersaline ecosystems such as salt lakes, soda lakes, solar salterns and saline soils show great variability in total salt concentration, ionic composition and $\mathrm{pH}$ (RodriguezValera, 1988; Oren, 2002). Members of the family Halobacteriaceae are ubiquitous in these hypersaline environments. They are aerobic or facultatively anaerobic, red-pigmented due to the presence of carotenoid pigments (except for a few species), chemo-organotrophic archaea requiring at least $1.5 \mathrm{M} \mathrm{NaCl}$ for growth (Grant et al., 2001; Ventosa, 2006). The halophilic archaea have been classified into 23 genera on the basis of $16 \mathrm{~S}$ rRNA gene sequence comparisons and chemotaxonomic criteria, particularly polar lipid composition, but there is no strict correlation between the two (Ventosa, 2006).

The GenBank/EMBL/DDBJ accession number for the $16 \mathrm{~S}$ rRNA gene sequence of strain EJ-32 ${ }^{\top}$ is AM491830.
At the time of writing the genus Halorubrum (McGenity \& Grant, 1995, 2001) contained 16 recognized species: Halorubrum aidingense (Cui et al., 2006), Halorubrum alkaliphilum (Feng et al., 2005), Halorubrum coriense (Kamekura \& Dyall-Smith, 1995; Oren \& Ventosa, 1996), Halorubrum distributum (Zvyagintseva \& Tarasov, 1987; Oren \& Ventosa, 1996), Halorubrum ezzemoulense (Kharroub et al., 2006), Halorubrum lacusprofundi (Franzmann et al., 1988), Halorubrum lipolyticum (Cui et al., 2006), Halorubrum orientale (Castillo et al., 2006), Halorubrum sodomense (Oren, 1983), Halorubrum tebenquichense (Lizama et al., 2002), Halorubrum terrestre (Ventosa et al., 2004), Halorubrum tibetense (Fan et al., 2004), Halorubrum trapanicum (Petter, 1931; McGenity \& Grant, 1995), Halorubrum vacuolatum (Mwatha \& Grant, 1993; Kamekura et al., 1997), Halorubrum xinjiangense (Feng et al., 2004) and Halorubrum saccharovorum (type species) (Tomlinson \& Hochstein, 1976). These species can be 
classified into two groups according to their growth at various $\mathrm{pH}$ values and their origins. Group 1 contains neutrophilic species, such as Hrr. aidingense, Hrr. coriense, Hrr. distributum, Hrr. ezzemoulense, Hrr. lacusprofundi, Hrr. lipolyticum, Hrr. orientale, Hrr. saccharovorum, Hrr. sodomense, Hrr. tebenquichense, Hrr. terrestre, Hrr. trapanicum and Hrr. xinjiangense. Group 2 contains three alkaliphilic species, Hrr. alkaliphilum, Hrr. tibetense and Hrr. vacuolatum (Grant et al., 2001).

Here, we report the isolation and description of a novel neutrophilic strain $\left(\mathrm{EJ}-32^{\mathrm{T}}\right)$ isolated from Lake Ejinor in Inner Mongolia, China, and its assignment as a novel species of the genus Halorubrum.

Strain EJ-32 ${ }^{\mathrm{T}}$ was isolated from a water sample collected from Lake Ejinor $\left(45^{\circ} 14^{\prime} \mathrm{N}, 116^{\circ} 32^{\prime} \mathrm{E}\right)$ in Inner Mongolia, China. At the time of sampling (September 2003) the water of the lake had a temperature of $32{ }^{\circ} \mathrm{C}$, a $\mathrm{pH}$ of 8.5 and a salinity of $18 \%(\mathrm{w} / \mathrm{v})$. The isolation procedure was as described previously (Castillo et al., 2006; Gutiérrez et al., 2007). Characterization of strain EJ-32 ${ }^{\mathrm{T}}$ was performed according to the proposed minimal standards for the description of novel taxa in the order Halobacteriales (Oren et al., 1997). Cell motility and morphology were examined by phase-contrast microscopy of exponentially growing liquid cultures by using an Olympus BX41 microscope equipped with phase-contrast optics. The cells of strain EJ- $32^{\mathrm{T}}$ were rod-shaped and nonmotile, with a tendency to form clumps. Colony morphology was observed under optimal growth conditions on agar medium with $25 \%(\mathrm{w} / \mathrm{v})$ salts, after incubation at $37{ }^{\circ} \mathrm{C}$ for 10 days. Anaerobic growth was tested in filled, stoppered tubes in the presence of $5 \mathrm{~g}$ nitrate $\mathrm{l}^{-1}$ or $5 \mathrm{~g}$ arginine $1^{-1}$. Tests for the following features were carried out as described by Oren et al. (1997): catalase and oxidase activities; hydrolysis of starch, Tween 80 , gelatin, casein, DNA and aesculin; reduction of nitrate and nitrite; formation of $\mathrm{H}_{2} \mathrm{~S}$ and indole; utilization of sugars, alcohols, amino acids and organic acids. Antibioticsensitivity tests were performed by spreading bacterial suspensions on culture plates and applying discs impregnated with the following concentrations ( $\mu \mathrm{g}$ unless indicated otherwise): ampicillin (10), bacitracin (10 U), cephalothin (30), chloramphenicol (30), erythromycin (15), gentamicin (10), kanamycin (30), nalidixic acid (30), neomycin (10), novobiocin (30), penicillin G (10 U), rifampicin (30), polymyxin (300 U), streptomycin (10), sulfamethoxazole (25), tetracycline (30) and vancomycin (30). The physiological and biochemical characteristics, as well as the antibiotic susceptibilities, of strain $\mathrm{EJ}-32^{\mathrm{T}}$ are provided in the species description below.

Polar lipids were extracted with chloroform/methanol as described by Kamekura (1993). TLC was performed using Merck HPTLC silica gel 60 plates (Art. 5641) in a solvent system comprising chloroform/methanol/acetic acid/water $(85: 22.5: 10: 4$, by vol.). The polar lipid composition of strain EJ-32 ${ }^{\mathrm{T}}$ comprised phosphatidylglycerol and phosphatidylglycerophosphate methyl ester, but no glycolipids were detected.

The 16S rRNA gene sequence was amplified by PCR using three universal primer sets as described by Lopez-Garcia et al. (2001) and Arahal et al. (1996), and the almostcomplete nucleotide sequence was determined by NBTNewbiotechnic (Sevilla, Spain) using an automated DNA sequencer (model 3100; Applied Biosystems). A subsequent sequence analysis was conducted using the ARB software package (Ludwig et al., 2004). Alternative treeing methods (maximum parsimony, neighbour joining and maximum likelihood) were used according to the recommendations of Ludwig et al. (1998). A comparison of 16S rRNA gene sequences revealed that the sequence of strain EJ- $32^{\mathrm{T}}$ (1404 bp) displayed the highest level of similarity with those of Halorubrum species. Fig. 1 shows the phylogenetic

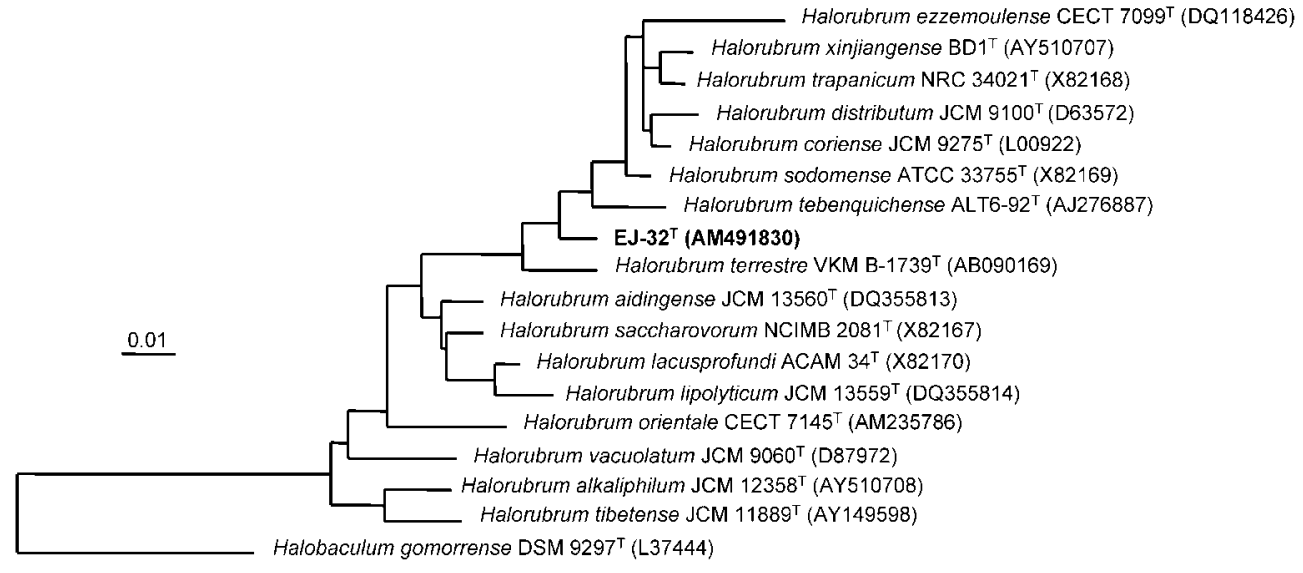

Fig. 1. Maximum-parsimony phylogenetic tree, based on $16 \mathrm{~S}$ rRNA gene sequences, showing the position of strain EJ-32 among the species of the genus Halorubrum. The sequence data used were obtained from the EMBL database (accession numbers are given in parentheses). Bar, $1 \%$ sequence divergence. 
tree constructed with the maximum-parsimony method (Fitch, 1971), in which strain EJ-32 ${ }^{\mathrm{T}}$ clustered with the type strains of species of the genus Halorubrum. Sequence similarity calculations indicated that strain $\mathrm{EJ}-32^{\mathrm{T}}$ was related to Hrr. coriense ( $97.9 \%$ sequence similarity), Hrr. trapanicum (97.9\%), Hrr. sodomense (97.8\%), Hrr. tebenquichense (97.8\%), Hrr. xinjiangense (97.6\%), Hrr. terrestre (97.4\%), Hrr. distributum (97.1\%) and Hrr. saccharovorum $(96.4 \%)$. Similar tree topologies were obtained when other tree-construction methods were used.

The DNA G $+\mathrm{C}$ content was determined from the midpoint $\left(T_{\mathrm{m}}\right)$ of the thermal denaturation profile (Marmur \& Doty, 1962), using the equation of Owen \& Hill (1979). The DNA G $+\mathrm{C}$ content of strain $\mathrm{EJ}-32^{\mathrm{T}}$ was $64.0 \mathrm{~mol} \%$, which is within the $\mathrm{G}+\mathrm{C}$ range reported for the species of the genus Halorubrum (62.7-71.2 mol\%) (Grant et al., 2001).

DNA-DNA hybridizations between strain EJ-32 $2^{\mathrm{T}}$ and the type strains of the phylogenetically most closely related Halorubrum species were performed using the competition procedure of Johnson (1994), as described in detail by
Gutierrez et al. (2002). The levels of DNA-DNA relatedness between strain EJ-32 ${ }^{\mathrm{T}}$ and Hrr. coriense JCM $9275^{\mathrm{T}}, H r r$. trapanicum NRC $34021^{\mathrm{T}}$, Hrr. sodomense ATCC $33755^{\mathrm{T}}$, Hrr. tebenquichense CECT $5317^{\mathrm{T}}$, Hrr. xinjiangense JCM $12388^{\mathrm{T}}$, Hrr. terrestre VKM B-1739 ${ }^{\mathrm{T}}$, Hrr. distributum JCM $9100^{\mathrm{T}}$ and $H r r$. saccharovorum NCIMB $2081^{\mathrm{T}}$ were 40,46 , $31,44,49,17,36$ and $3 \%$, respectively. These levels of DNA-DNA hybridization are low enough to justify the classification of strain $\mathrm{EJ}-32^{\mathrm{T}}$ as representing a genotypically distinct species within the genus Halorubrum (Wayne et al., 1987; Stackebrandt \& Goebel, 1994).

The differentiating characteristics of strain EJ- $32^{\mathrm{T}}$ compared with those of the other Halorubrum species are listed in Table 1. Overall, our data show that strain EJ-52 ${ }^{\mathrm{T}}$ represents a novel species of the genus Halorubrum, for which the name Halorubrum ejinorense sp. nov. is proposed.

\section{Description of Halorubrum ejinorense sp. nov.}

Halorubrum ejinorense (e.ji.no.ren'se. N.L. neut. adj. ejinorense of Ejinor, referring to the isolation of the organism from the saline Lake Ejinor, in Inner Mongolia, China).

Table 1. Characteristics that distinguish strain $E J-32^{\top}$ from non-alkaliphilic Halorubrum species

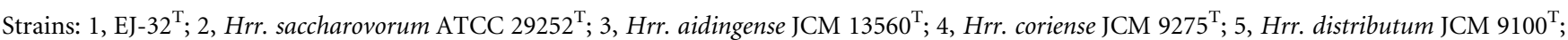
6, Hrr. ezzemoulense CECT $7099^{\mathrm{T}}$; 7, Hrr. lacusprofundi JCM 8891 ${ }^{\mathrm{T}} ; 8$, Hrr. lipolyticum JCM $13559^{\mathrm{T}}$; 9, Hrr. orientale CECT $7145^{\mathrm{T}}$; 10 , Hrr. sodomense ATCC $33755^{\mathrm{T}}$; 11, Hrr. tebenquichense DSM $14210^{\mathrm{T}}$; 12, Hrr. terrestre VKM B-1739 ${ }^{\mathrm{T}}$; 13, Hrr. trapanicum JCM 10477 ${ }^{\mathrm{T}}$; 14 , Hrr. xinjiangense AS $1.3527^{\mathrm{T}}$. Data are from Cui et al. (2006), Kharroub et al. (2006), Feng et al. (2004), Ventosa et al. (2004), Lizama et al. (2002), McGenity \& Grant (2001), Feng et al. (2005) and this study. +, Positive; -, negative; +/-, doubtful; ND, not determined.

\begin{tabular}{|c|c|c|c|c|c|c|c|c|c|c|c|c|c|c|}
\hline Characteristic & 1 & 2 & 3 & 4 & 5 & 6 & 7 & 8 & 9 & 10 & 11 & 12 & 13 & 14 \\
\hline Morphology & Rods & Rods & Rods & $\begin{array}{c}\text { Pleo- } \\
\text { morphic } \\
\text { short rods } \\
\text { and cup } \\
\text { shapes }\end{array}$ & $\begin{array}{l}\text { Pleo- } \\
\text { morphic } \\
\text { rods }\end{array}$ & $\begin{array}{l}\text { Pleo- } \\
\text { morphic } \\
\text { rods }\end{array}$ & $\begin{array}{l}\text { Pleo- } \\
\text { morphic } \\
\text { rods }\end{array}$ & Rods & $\begin{array}{l}\text { Pleo- } \\
\text { morphic } \\
\text { rods }\end{array}$ & Rods & $\begin{array}{l}\text { Irregular } \\
\text { discs }\end{array}$ & $\begin{array}{l}\text { Pleo- } \\
\text { morphic }\end{array}$ & $\begin{array}{l}\text { Pleo- } \\
\text { morphic } \\
\text { rods }\end{array}$ & $\begin{array}{r}\text { Short } \\
\text { rods }\end{array}$ \\
\hline \multirow[t]{3}{*}{ Cell size $(\mu \mathrm{m})$} & $1.0-1.5$ & $0.6-1.2$ & $0.9-1.0$ & $5.0-0.5$ & $0.8-1.0$ & $0.6-1.5$ & $>12$ & $0.9-1.2$ & $1.5-2.0$ & 0.5 & $0.8-1.2$ & $1.0-1.5$ & $0.7-1.0$ & $0.8-1.2$ \\
\hline & $\times$ & $\times$ & $\times$ & & $\times$ & $\times$ & & $\times$ & $\times$ & $\times$ & $\times$ & $\times$ & $\times$ & $\times$ \\
\hline & $5.0-8.0$ & 2.5 & $3.6-6.4$ & & $2.7-7.0$ & 3.0 & & $1.8-5.5$ & $1.0-2.0$ & $2.5-5$ & $1.5-1.0$ & $1.5-2.5$ & $1.5-3.0$ & $1.8-2.6$ \\
\hline Motility & - & + & + & + & + & + & + & + & + & + & $\mathrm{ND}$ & + & - & + \\
\hline $\begin{array}{l}\text { Colony } \\
\text { pigmentation }\end{array}$ & Red & $\begin{array}{c}\text { Orange- } \\
\text { red }\end{array}$ & Red & $\begin{array}{c}\text { Orange- } \\
\text { red }\end{array}$ & $\begin{array}{c}\text { Orange- } \\
\text { red }\end{array}$ & Red & Red & Red & Red & $\begin{array}{c}\text { Orange- } \\
\text { red }\end{array}$ & $\begin{array}{l}\text { Red- } \\
\text { orange }\end{array}$ & $\begin{array}{c}\text { Orange- } \\
\text { red }\end{array}$ & $\begin{array}{l}\text { Pale } \\
\text { orange }\end{array}$ & Red \\
\hline $\begin{array}{l}\mathrm{NaCl} \text { range for } \\
\text { growth (M) }\end{array}$ & $2.5-5.0$ & $1.5-5.2$ & $1.7-4.3$ & $2.0-5.2$ & $1.7-5.2$ & $2.5-4.3$ & $1.5-5.2$ & $1.7-4.8$ & $2.5-5.0$ & $0.5-4.3$ & $2.5-5.2$ & $2.5-5.2$ & $2.5-5.2$ & $2.0-5.2$ \\
\hline $\begin{array}{l}\text { Temperature } \\
\text { optimum } \\
\left({ }^{\circ} \mathrm{C}\right)\end{array}$ & 37 & 50 & $40-42$ & 50 & $37-45$ & $37-40$ & $31-37$ & $45-48$ & 37 & 40 & 40 & $37-45$ & 37 & 40 \\
\hline $\begin{array}{l}\text { Nitrate } \\
\text { reduction }\end{array}$ & + & - & + & $\mathrm{ND}$ & + & + & $+1-$ & + & + & $+1-$ & + & - & + & - \\
\hline $\begin{array}{l}\mathrm{H}_{2} \mathrm{~S} \\
\text { production }\end{array}$ & - & + & + & ND & + & ND & - & + & - & ND & + & - & ND & + \\
\hline \multicolumn{15}{|l|}{ Utilization of: } \\
\hline D-Fructose & - & + & + & ND & ND & - & - & + & + & + & + & - & + & + \\
\hline Lactose & - & + & - & + & $\mathrm{ND}$ & - & + & - & - & + & - & $\mathrm{ND}$ & - & - \\
\hline D-Galactose & - & + & + & + & - & - & + & + & - & - & + & $\mathrm{ND}$ & + & - \\
\hline Maltose & - & + & + & ND & $\mathrm{ND}$ & ND & - & + & + & + & - & $\mathrm{ND}$ & + & + \\
\hline D-Glucose & - & + & + & + & - & + & + & + & + & + & + & - & + & + \\
\hline Sucrose & - & + & + & $\mathrm{ND}$ & - & + & $\mathrm{ND}$ & + & $\mathrm{ND}$ & + & - & $\mathrm{ND}$ & + & + \\
\hline $\begin{array}{c}\text { DNA G + C } \\
\text { content } \\
(\mathrm{mol} \%)\end{array}$ & 64.0 & 71.2 & 64.2 & ND & 63.6 & 61.9 & 65.3 & 65.9 & 64.2 & 67.4 & 63.2 & 64.4 & 64.3 & 68.0 \\
\hline
\end{tabular}


Cells are Gram-negative rods $1.0-1.5 \times 5.0-8.0 \mu \mathrm{m}$ in size. Colonies on agar plates containing $25 \%(\mathrm{w} / \mathrm{v})$ total salt are red, elevated and round. Growth occurs with 2.5-5.0 M $\mathrm{NaCl}$ at $\mathrm{pH} 6-10$ and $25-50{ }^{\circ} \mathrm{C}$. The optimal $\mathrm{NaCl}$ concentration, $\mathrm{pH}$ and temperature for growth are $3.4 \mathrm{M}$, pH 7.5 and $37{ }^{\circ} \mathrm{C}$, respectively. Magnesium is not required for growth. Chemo-organotrophic and aerobic. Catalaseand oxidase-positive. Anaerobic growth with nitrate or Larginine does not occur and nitrate reduction to nitrite is observed. $\mathrm{H}_{2} \mathrm{~S}$ is not produced from cysteine. Indole is not produced from tryptophan. Methyl red, Voges-Proskauer and Simmons citrate test results are negative. Tween 80 and DNA are hydrolysed. Casein, gelatin and starch are not hydrolysed. Acid is not produced from D-arabinose, Dfructose, D-galactose, D-glucose, glycerol, lactose, maltose, D-mannitol, sucrose, trehalose or D-xylose. Arginine dihydrolase, lysine decarboxylase and ornithine decarboxylase are not produced. Growth occurs on trehalose as a single carbon and energy source. The following compounds are not used as sole carbon and energy sources: acetate, Darabinose, fumarate, D-fructose, D-glucose, D-glutamate, glycerol, lactose, malate, maltose, D-mannitol, propionate, D-raffinose, D-ribose, D-sorbitol, succinate and D-xylose. The following compounds are used as sole carbon, nitrogen or energy sources: L-asparagine, isoleucine, L-lysine and Lthreonine. Serine and glycine are not used as sole carbon, nitrogen or energy sources. Susceptible to bacitracin (10 U) and novobiocin $(30 \mu \mathrm{g})$. Resistant to the following antibiotics ( $\mu \mathrm{g}$ unless indicated otherwise): ampicillin (10), cephalothin (30), chloramphenicol (30), erythromycin (15), gentamicin (10), kanamycin (30), nalidixic acid (30), neomycin (10), penicillin $\mathrm{G}(10 \mathrm{U})$, rifampicin (30), polymyxin (300 U), streptomycin (10), sulfamethoxazole (25), tetracycline (30) and vancomycin (30). The polar lipids are phosphatidylglycerol and phosphatidylglycerophosphate methyl ester. Glycolipids not detected. The DNA G+C content is $64.0 \mathrm{~mol} \%$.

The type strain, EJ-32 ${ }^{\mathrm{T}} \quad\left(=\mathrm{CECT} \quad 7194^{\mathrm{T}}=\mathrm{CGMCC}\right.$ $\left.1.6782^{\mathrm{T}}=\mathrm{JCM} 14265^{\mathrm{T}}\right)$, was isolated from Lake Ejinor, a salt lake in Inner Mongolia, China.

\section{Acknowledgements}

This study was supported by grants from the Quality of Life and Management of Living Resources Programme of the European Commission (project 'Multigenome Access Technology for Industrial Catalysts'; QLK3-CT-2002-01972), the Spanish Ministerio de Educación y Ciencia (BIO2006-06927) and the Junta de Andalucia.

\section{References}

Arahal, D. R., Dewhirst, F. E., Paster, B. J., Volcani, B. E. \& Ventosa, A. (1996). Phylogenetic analyses of some extremely halophilic archaea isolated from Dead Sea water, determined on the basis of their $16 \mathrm{~S}$ rRNA sequences. Appl Environ Microbiol 62, 3779-3786.

Castillo, A. M., Gutiérrez, M. C., Kamekura, M., Xue, Y., Ma, Y., Cowan, D. A., Jones, B. E., Grant, W. D. \& Ventosa, A. (2006). Halorubrum orientale sp. nov., a halophilic archaeon isolated from
Lake Ejinor, Inner Mongolia, China. Int J Syst Evol Microbiol 56, 2559-2563.

Cui, H.-L., Tohty, D., Zhou, P.-J. \& Liu, S.-J. (2006). Halorubrum lipolyticum sp. nov. and Halorubrum aidingense sp. nov., isolated from two salt lakes in Xin-Jiang, China. Int J Syst Evol Microbiol 56, 1631-1634.

Fan, H., Xue, Y., Ma, Y., Ventosa, A. \& Grant, W. D. (2004). Halorubrum tibetense sp. nov., a novel haloalkaliphilic archaeon from Lake Zabuye in Tibet, China. Int J Syst Evol Microbiol 54, 1213-1216.

Feng, J., Zhou, P. \& Liu, S. (2004). Halorubrum xinjiangense sp. nov., a novel halophile isolated from saline lakes in China. Int J Syst Evol Microbiol 54, 1789-1791.

Feng, J., Zhou, P., Zhou, Y., Liu, S. \& Warren-Rhodes, K. (2005). Halorubrum alkaliphilum sp. nov., a novel haloalkaliphile isolated from a soda lake in Xinjiang, China. Int J Syst Evol Microbiol 55, 149-152.

Fitch, W. M. (1971). Towards defining the course of evolution: minimum change for a specific tree topology. Syst Zool 20, 406-416.

Franzmann, P. D., Stackebrandt, E., Sanderson, K., Volkman, J. K., Cameron, D. E., Stevenson, P. L., McMeekin, T. A. \& Burton, H. R. (1988). Halobacterium lacusprofundi sp. nov., a halophilic bacterium isolated from Deep Lake, Antarctica. Syst Appl Microbiol 11, 20-27.

Grant, W. D., Kamekura, M., McGenity, T. J. \& Ventosa, A. (2001). Order I. Halobacteriales Grant \& Larsen 1989b, 495 ${ }^{\mathrm{VP}}$ (Effective publication: Grant \& Larsen 1989a, 2216). In Bergey's Manual of Systematic Bacteriology, 2nd edn, vol. 1, pp. 294-334. Edited by D. R. Boone, R. W. Castenholz \& G. M. Garrity. New York: Springer.

Gutiérrez, M. C., Kamekura, M., Holmes, M. L., Dyall-Smith, M. L. \& Ventosa, A. (2002). Taxonomic characterization of Haloferax sp. (" $H$. alicantei") strain Aa 2.2: description of Haloferax lucentesis sp. nov. Extremophiles 6, 479-483.

Gutiérrez, M. C., Castillo, A. M., Kamekura, M., Xue, Y., Ma, Y., Cowan, D. A., Jones, B. E., Grant, W. D. \& Ventosa, A. (2007). Halopiger xanaduensis gen. nov., sp. nov., an extremely halophilic archaeon isolated from saline Lake Shangmatala in Inner Mongolia, China. Int J Syst Evol Microbiol 57, 1402-1407.

Johnson, J. L. (1994). Similarity analysis of DNAs. In Methods for General and Molecular Biotechnology, pp. 655-681. Edited by P. Gerhardt, R. G. E. Murray, W. A. Wood \& N. R. Krieg. Washington, DC: American Society for Microbiology.

Kamekura, M. (1993). Lipids of extreme halophiles. In The Biology of Halophilic Bacteria, pp. 135-161. Edited by R. H. Vreeland \& L. I. Hochstein. Boca Raton: CRC Press.

Kamekura, M. \& Dyall-Smith, M. L. (1995). Taxonomy of the family Halobacteriaceae and the description of two genera Halorubrobacterium and Natrialba. J Gen Appl Microbiol 41, 333-350.

Kamekura, M., Dyall-Smith, M. L., Upasani, V., Ventosa, A. \& Kates, M. (1997). Diversity of alkaliphilic halobacteria: proposals for transfer of Natronobacterium vacuolatum, Natronobacterium magadii, and Natronobacterium pharaonis to Halorubrum, Natrialba and Natronomonas gen. nov., respectively, as Halorubrum vacuolatum comb. nov., Natrialba magadii comb. nov., and Natronomonas pharaonis comb. nov., respectively. Int J Syst Bacteriol 47, 853-857.

Kharroub, K., Quesada, E., Ferrer, R., Fuentes, S., Aguilera, M., Boulahrouf, A., Ramos-Cormenzana, A. \& Monteoliva-Sánchez, M. (2006). Halorubrum ezzemoulense sp. nov., a halophilic archaeon isolated from Ezzemoul sabkha, Algeria. Int J Syst Evol Microbiol 56, 1583-1588.

Lizama, C., Monteoliva-Sanchez, M., Suarez-Garcia, A., RoselloMora, R., Aguilera, M., Campos, V. \& Ramos-Cormenzana, A. (2002). Halorubrum tebenquichense sp. nov., a novel halophilic archaeon isolated from the Atacama Saltern, Chile. Int J Syst Evol Microbiol 52, 149-155. 
Lopez-Garcia, P., Moreira, D., Lopez-Lopez, A. \& Rodríguez-Valera, F. (2001). A novel haloarchaeal-related lineage is widely distributed in deep oceanic regions. Environ Microbiol 3, 72-78.

Ludwig, W., Strunk, O., Klugbauer, S., Klugbauer, N., Weizenernegger, M., Neumaier, J., Bachleitner, M. \& Schleifer, K.-H. (1998). Bacterial phylogeny based on comparative sequence analysis. Electrophoresis 19, 554-568.

Ludwig, W., Strunk, O., Westram, R., Richter, L., Meier, H., Yadhukumar, Buchner, A., Lai, T., Steppi, S. \& other authors (2004). ARB: a software environment for sequence data. Nucleic Acids Res 32, 1363-1371.

Marmur, J. \& Doty, P. (1962). Determination of the base composition of deoxyribonucleic acid from its thermal denaturation temperature. J Mol Biol 5, 109-118.

McGenity, T. J. \& Grant, W. D. (1995). Transfer of Halobacterium saccharovorum, Halobacterium sodomense, Halobacterium trapanicum NRC 34021 and Halobacterium lacusprofundi to the genus Halorubrum gen. nov., as Halorubrum saccharovorum comb nov., Halorubrum sodomense comb nov., Halorubrum trapanicum comb. nov., and Halorubrum lacusprofundi comb. nov. Syst Appl Microbiol 18, 237-243.

McGenity, T. J. \& Grant, W. D. (2001). Genus VII. Halorubrum. In Bergey's Manual of Systematic Bacteriology, 2nd edn, vol. 1, pp. 320324. Edited by D. R. Boone, R. W. Castenholz \& G. M. Garrity. New York: Springer.

Mwatha, W. E. \& Grant, W. D. (1993). Natronobacterium vacuolata sp. nov., a haloalkaliphilic archaeon isolated from Lake Magadi, Kenya. Int J Syst Bacteriol 43, 401-404.

Oren, A. (1983). Halorubrum sodomense sp. nov., a Dead Sea halobacterium with an extremely high magnesium requirement. Int J Syst Bacteriol 33, 381-386.

Oren, A. (2002). Halophilic Microorganisms and their Environments. Dordrecht: Kluwer Academic Publishers.

Oren, A. \& Ventosa, A. (1996). A proposal for the transfer of Halorubrobacterium distributum and Halorubrobacterium coriense to the genus Halorubrum as Halorubrum distributum comb. nov. and Halorubrum coriense comb. nov., respectively. Int J Syst Bacteriol 46, 1180.
Oren, A., Ventosa, A. \& Grant, W. D. (1997). Proposed minimal standards for description of new taxa in the order Halobacteriales. Int $J$ Syst Bacteriol 47, 233-238.

Owen, R. J. \& Hill, L. R. (1979). The estimation of base compositions, base pairing and genome sizes of bacterial deoxyribonucleic acids. In Identification Methods for Microbiologists (Society for Applied Bacteriology Technical Series no. 14), 2nd edn, pp. 277-296. Edited by F. A. Skinner \& D. W. Lovelock. London: Academic Press.

Petter, H. F. M. (1931). On bacteria of salted fish. Proc K Ned Akad Wet Amsterdam 34, 1417-1423 (in Dutch).

Rodriguez-Valera, F. (1988). Characteristics and microbial ecology of hypersaline environments. In Halophilic Bacteria, vol. 1, pp. 3-30. Edited by F. Rodriguez-Valera. Boca Raton: CRC Press.

Stackebrandt, E. \& Goebel, B. M. (1994). Taxonomic note: a place for DNA-DNA reassociation and $16 \mathrm{~S}$ rRNA sequence analysis in the present species definition in bacteriology. Int J Syst Bacteriol 44, 846-849.

Tomlinson, G. A. \& Hochstein, L. I. (1976). Halobacterium saccharovorum sp. nov., a carbohydrate-metabolizing, extremely halophilic bacterium. Can J Microbiol 22, 587-591.

Ventosa, A. (2006). Unusual micro-organisms from unusual habitats: hypersaline environments. In Prokaryotic Diversity: Mechanisms and Significance, pp. 223-253. Edited by N. A. Logan, H. M. Lappin-Scott \& P. C. F. Oyston. Cambridge: Cambridge University Press.

Ventosa, A., Gutiérrez, M. C., Kamekura, M., Zvyagintseva, I. S. \& Oren, A. (2004). Taxonomic study of Halorubrum distributum and proposal of Halorubrum terrestre sp. nov. Int J Syst Evol Microbiol 54, 389-392.

Wayne, L. G., Brenner, D. J., Colwell, R. R., Grimont, P. A. D., Kandler, O., Krichevsky, M. I., Moore, L. H., Moore, W. E. C., Murray, R. G. E. \& other authors (1987). International Committee on Systematic Bacteriology. Report of the ad hoc committee on reconciliation of approaches to bacterial systematics. Int J Syst Bacteriol 37, 463-464.

Zvyagintseva, I. S. \& Tarasov, A. L. (1987). Extreme halophilic bacteria from saline soils. Microbiology (English translation of Mikrobiologiya) 56, 839-844 (in Russian). 